\title{
PHYLOGENETIC POSITION AND GENERIC PLACEMENT OF THE SOCORRO WREN (THRYOMANES SISSONII)
}

\author{
Juan E. Martínez Gómez ${ }^{1,4}$ Brian R. Barber, ${ }^{2}$ and A. Townsend Peterson ${ }^{3,5}$ \\ ${ }^{1}$ Department of Biology, University of Missouri-St. Louis, 8001 Natural Bridge Road, St. Louis, Missouri 63121, USA; \\ ${ }^{2}$ J. F. Bell Museum of Natural History, University of Minnesota, St. Paul, Minnesota 55108, USA; and \\ ${ }^{3}$ Instituto de Biología, Universidad Nacional Autónoma de México, D.F. 04510, México.
}

Aвstract. - Since early in its taxonomic history, placement of the Socorro Wren (Thryomanes sissonii) has been an object of contention. Of particular interest is its current placement in the genus Thryomanes, which makes that genus ditypic and leads to an odd biogeographic scenario for the Socorro Wren's colonization of Socorro Island. We assessed its phylogenetic position by analyzing 516 base pairs of mitochondrial DNA sequences from the ND2 gene of this species and 14 additional wren taxa. Contrary to its present placement, the Socorro Wren is nested phylogenetically within the House Wren species complex, being placed as sister to the clade Troglodytes aedon + T. musculus. The current hypothesis (i.e. sister to Thryomanes bewickii) is strongly invalidated by our analysis. Our analyses indicate that the most appropriate taxonomic classification for the Socorro Wren is Troglodytes sissonii. Received 29 January 2003, accepted 20 July 2004.

Key words: Revillagigedo Archipelago, Socorro Island, Socorro Wren, Thryomanes sissonii, Troglodytes sissonii.

\section{Posición Filogenética y Ubicación Genérica de Thryomanes sissonii}

Resumen.-Desde el comienzo de su historia taxonómica, la ubicación de Thryomanes sissonii, una especie de troglodítido endémica de la isla Socorro, ha sido objeto de controversia. De particular interés es su ubicación actual en el género Thryomanes, la cual hace que este género sea ditípico y plantea un escenario biogeográfico extraño en cuanto a la colonización de Socorro por parte de esta especie. En este estudio determinamos la posición filogenética de T. sissonii analizando secuencias de 516 pares de bases del gen mitocondrial ND2 para esta especie y para 14 taxa adicionales de la famila Troglodytidae. En contraste con su ubicación actual, $T$. sissonii se encuentra anidado filogenéticamente al interior del complejo de Troglodytes aedon, como la especie hermana del clado formado por T. aedon y T. musculus. La hipótesis actual (i.e. que la especie es hermana de Thryomanes bewickii) es fuertemente invalidada por nuestros análisis. Nuestros resultados indican que la clasificación taxonómica más adecuada para esta especie es Troglodytes sissonii.

The Socorro Wren (Thryomanes sissonii) is an endemic taxon of Socorro Island, an island off the west coast of Mexico $\left(18^{\circ} 47^{\prime} \mathrm{N}, 110^{\circ} 59^{\prime} \mathrm{W}\right)$. The taxonomic affinities of this species have

\footnotetext{
${ }^{4}$ E-mail: mimodes@jinx.umsl.edu

${ }^{5}$ Present address: Natural History Museum, University of Kansas, Lawrence, Kansas 66045, USA.
}

remained unclear for more than a century, and its placement in either Thryomanes or Troglodytes remains unresolved. The Socorro Wren was first collected by Andrew Jackson Grayson during his expedition to Socorro Island in 1865. Upon arrival in mainland Mexico, he sent all of his specimens to the Smithsonian Institution and granted permission to S. F. Baird to classify the new taxa (Bryant 1891). Later, he decided to 
describe them himself and classified the Socorro Wren as Thryothorus sissonii (Grayson 1868). Although uncertain of his generic allocation (for lack of comparative specimen material), he considered it the most appropriate at the time.

His description published in The California Farmer went unnoticed by ornithologists, including Grayson's most sincere admirers (e.g. Lawrence 1871, Bryant 1891). Contrary to Phillips (1986), Grayson never admitted that his descriptions were improperly published. After he died in 1869, G. N. Lawrence's posthumous publication of Grayson (1871) led to the misunderstanding.

Unaware of Grayson's earlier description, Lawrence (1871) described the Socorro Wren as Troglodytes insularis. He noted a striking similarity between the Socorro Wren and T. aedon [ $=$ musculus] inquietus from Panama. Oberholser (1898) moved the species to the genus Thryomanes solely on the basis of bill depth and shape of the nares. That generic placement soon became firmly established (e.g. Ridgway 1904, McLellan 1926). Thus, the Socorro Wren was set as Thryomanes insularis, in spite of Lawrence's (1871) original placement in the genus Troglodytes.

Taylor (1951) concurred with Oberholser's placement of the species in Thryomanes, and that placement was followed by taxonomic authorities (e.g. Mayr and Short 1970, American Ornithologists' Union [AOU] 1998), though a few workers have since voiced doubts (Phillips 1986, Howell and Webb 1995). Taylor (1951), however, challenged the priority of Lawrence's (1871) description, providing evidence of Grayson's original work. Hence, Grayson's original specific epithet sissonii was revived for the taxon, and has been maintained since (Banks and Browning 1995).

The objective of the present study is to reevaluate the case in the light of new evidence. On the basis of newly available tissue specimens of the species, and prior phylogenetic studies of the Troglodytidae, we performed additional analyses using mitochondrial DNA (mtDNA) sequences to elucidate the relationships of this enigmatic species. Below, we provide taxonomic recommendations for the Socorro Wren.

\section{Methods}

To determine the phylogenetic position of the Socorro Wren, we obtained partial mtDNA sequences from this species, five additional wren taxa, and one outgroup (Table 1) and combined them with sequences from GenBank (deposited by Rice et al. 1999). We used Certhia americana as a more appropriate outgroup than Rice et al.'s (1999) Gymnorhinus cyanocephalus (a very distant taxon) and Henicorhina leucosticta (a taxon appearing as sister to Troglodytes [Nannus] troglodytes in their phylogeny). Thus, the mtDNA sequence data set consisted of 516 base pairs (bp) of the ND2 gene for 15 wren taxa, plus 1 outgroup taxon.

We extracted whole-genomic DNA from muscle tissues and a blood sample of the Socorro Wren using QIAmp tissue extraction kit, following manufacturer's protocols (Qiagen, Valencia, California). We obtained sequences via polymerase chain reactions (PCR) using TAQ DNA polymerase (Promega, Madison, Wiscon$\sin )$ for the entire ND2 gene, using the primers L5215 (5'-TATCGGGCCCATACCCCGAATAT3'), developed by Hackett (1996), and H1064 (5'-CTTTGAAGGCCTTCGGTTTA-3'), equivalent to position 6,297 in the Desjardins and Morais (1990) nomenclature and developed by Drovetski et al. (2004). Amplification was carried out for 35 cycles under the following profile: an initial $94^{\circ} \mathrm{C}$ hotstart for $150 \mathrm{~s}, 94^{\circ} \mathrm{C}$ denaturing for $30 \mathrm{~s}, 55^{\circ} \mathrm{C}$ annealing for $30 \mathrm{~s}$, extension at $72^{\circ} \mathrm{C}$ for $70 \mathrm{~s}$, and terminal extension at $72^{\circ} \mathrm{C}$ for $10 \mathrm{~min}$. We purified PCR products using QIAquick PCR purification (Qiagen).

We sequenced PCR products for both primers on an ABI 3700 automated sequencer (Applied Biosystems, Foster, California), following manufacturer's protocols. We aligned and edited sequences with SEQUENCHER, version 3.1.1 (Gene Code Corporation, Ann Arbor, Michigan). All sequences were deposited in GenBank (AY465888-AY465894). Although we obtained the entire ND2 gene sequence, we used only that portion of the gene available from Rice et al. (1999); their data set contained $534 \mathrm{bp}$, of which 18 were beyond the $3^{\prime}$ end of the ND2 gene and were not included in our analyses.

To ensure that the sequences used were of mitochondrial origin, we examined them for insertions, deletions (indels), and internal stop codons: indels and internal stop codons would be observed if sequences did not code for proteins. We observed no indels or internal stop codons, and so we are confident that we obtained mitochondrial sequence data. 


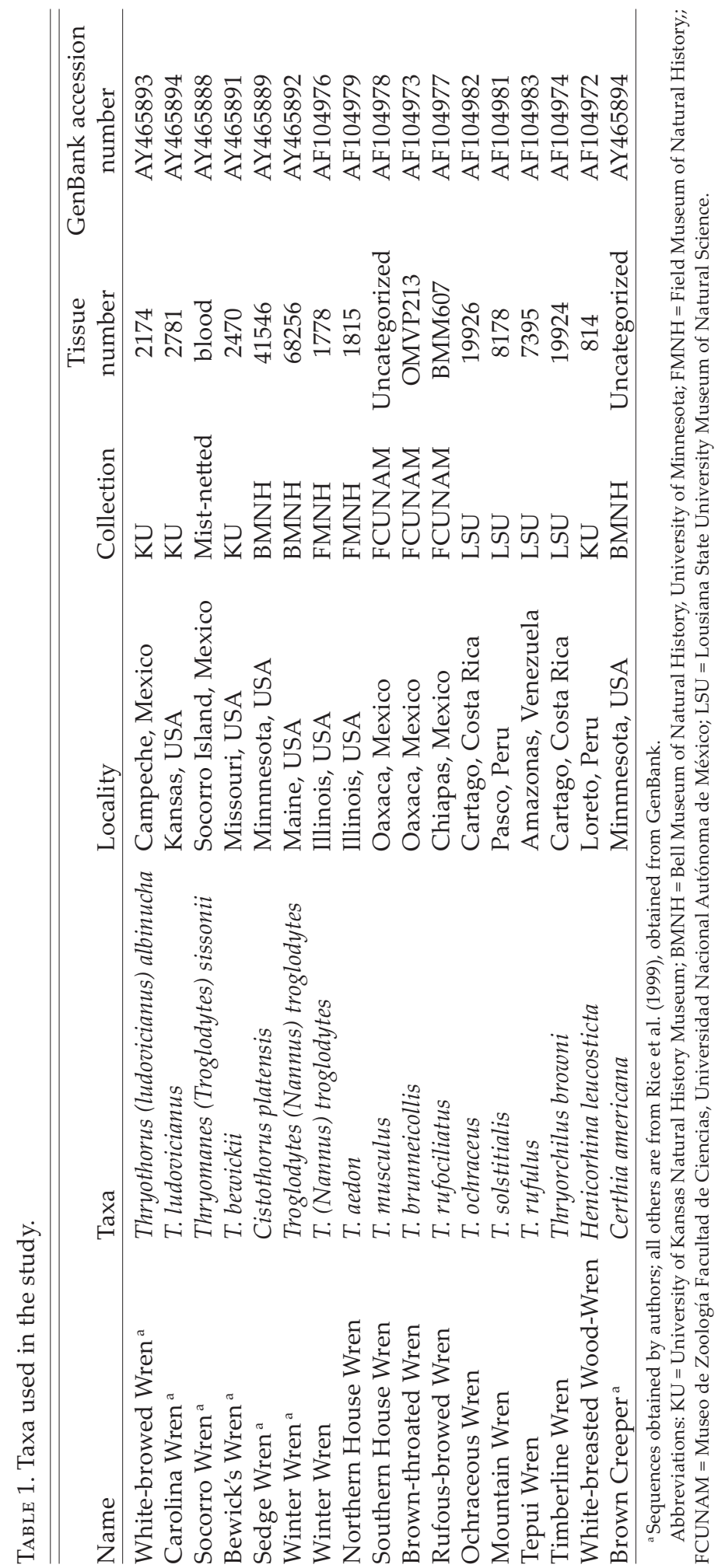


We conducted parsimony analyses in PAUP*, version 4.0b.10 (Swofford 2002), using a branch-and-bound search with all positions and transversions-transitions weighted equally (tree bisection reconnection [TBR] is an option only in heuristic searches). Additional analyses were carried out under the following transversion-transition weighting schemes: $2 / 1,4 / 1,8 / 1$, and 10/1. We determined support for each node via heuristic bootstraps $(1,000$ replicates; Felsenstein 1985). We calculated Bremer support values for the equally weighted parsimony tree (Bremer 1988) using TREEROT (Sorenson 1999).

For maximum likelihood (ML), we used MODELTEST, version 3.06 (Posada and Crandall 1998) to determine the model that best explained the data, using a hierarchical likelihood ratio test. We determined nodal support for the maximum likelihood analysis via branch-and-bound bootstraps with 100 replicates. Bayesian analyses were implemented in MRBAYES, version 2.01 (Huelsenbeck and Ronquist 2001).

In the Bayesian analyses, the gamma-shape parameter and base frequencies were not defined a priori; instead, those parameters were treated as unknowns to be estimated during the analysis. Markov chain Monte Carlo (MCMC) simulations via four chains were run for 2,000,000 generations; for every 100 generations, a data point was saved for subsequent analysis. Random swapping between chains decreases the likelihood that an individual chain will be trapped in a local optima. A plot (not shown) of likelihood values versus generation determined that the likelihood values leveled off at $\sim 50,000$ generations.

To ensure that subsequent analyses were not biased by "burn-in" trees, we removed the first 99,900 generations, or the first 999 trees; we retained the remaining 19,001 trees for additional analysis. "Burn-in" trees are those trees obtained before the log-likelihood values reach stationarity and are discarded before posterior probabilities are calculated.) We obtained a 50\% majority rule consensus tree from those remaining trees. Percentage of times a given node appears in the posterior distribution of retained trees is interpreted as the posterior probability of that node (Huelsenbeck and Ronquist 2001). We examined alternative phylogenetic hypotheses by creating user-determined trees and comparing that topology with the equally weighted parsimony tree using a Shimodaira and Hasegawa (1999) test.

\section{Results}

Of 516 bp of the ND2 gene analyzed, 245 were variable and 157 were phylogenetically informative; of those $157 \mathrm{bp}, 34$ were in first-codon positions, 16 in second-codon positions, and 107 in third-codon positions. Parsimony analysis using a branch-and-bound search resulted in a single most-parsimonious tree of 519 steps (consistency index $[\mathrm{CI}]=0.6243$, retention index $[R I]=0.5768$; Fig. 1). The CI, with uninformative characters excluded, was 0.5301 .

The critical node for our analyses is that linking Thryomanes sissonii, Troglodytes aedon, and T. musculus. That clade received unequivocal bootstrap support in all analyses, including a posterior probability of 1.0 in the Bayesian analysis (Fig. 1). Those taxa, together with T. brunneicollis, are part of a larger clade that makes up the House Wren complex; all parsimony analyses (not shown) using the different transversiontransition weighting schemes recovered this clade (clade A; Fig. 1). That is, in combination with the strong support for a node with Thryomanes bewickii + Thryothorus ludovicianus, the preceding results confirm that the Socorro Wren is not related to Bewick's Wren, and is in fact nested within Troglodytes. A Shimodaira and Hasegawa (1999) test significantly $(P<$ $0.05)$ rejected the user-defined tree that placed Thryomanes sissonii as sister to T. bewickii as a better explanation of the data versus the equally weighted parsimony tree.

\section{Discussion}

Thryomanes sissonii was placed with high support as a lineage basal to Troglodytes aedon and T. musculus under three distinct optimality criteria and numerous models of molecular evolution (Fig. 1). Moreover, the Socorro Wren is part of the House Wren complex and of a larger clade containing members of Troglodytes. Although the topology of those clades might change with the addition of other taxa (e.g. other insular forms of Troglodytes), it should be expected that the monophyly of Troglodytes would be supported, with the exception of Troglodytes [= Nannus] troglodytes.

Rice et al. (1999) observed that T. troglodytes did not appear within the clade containing the 

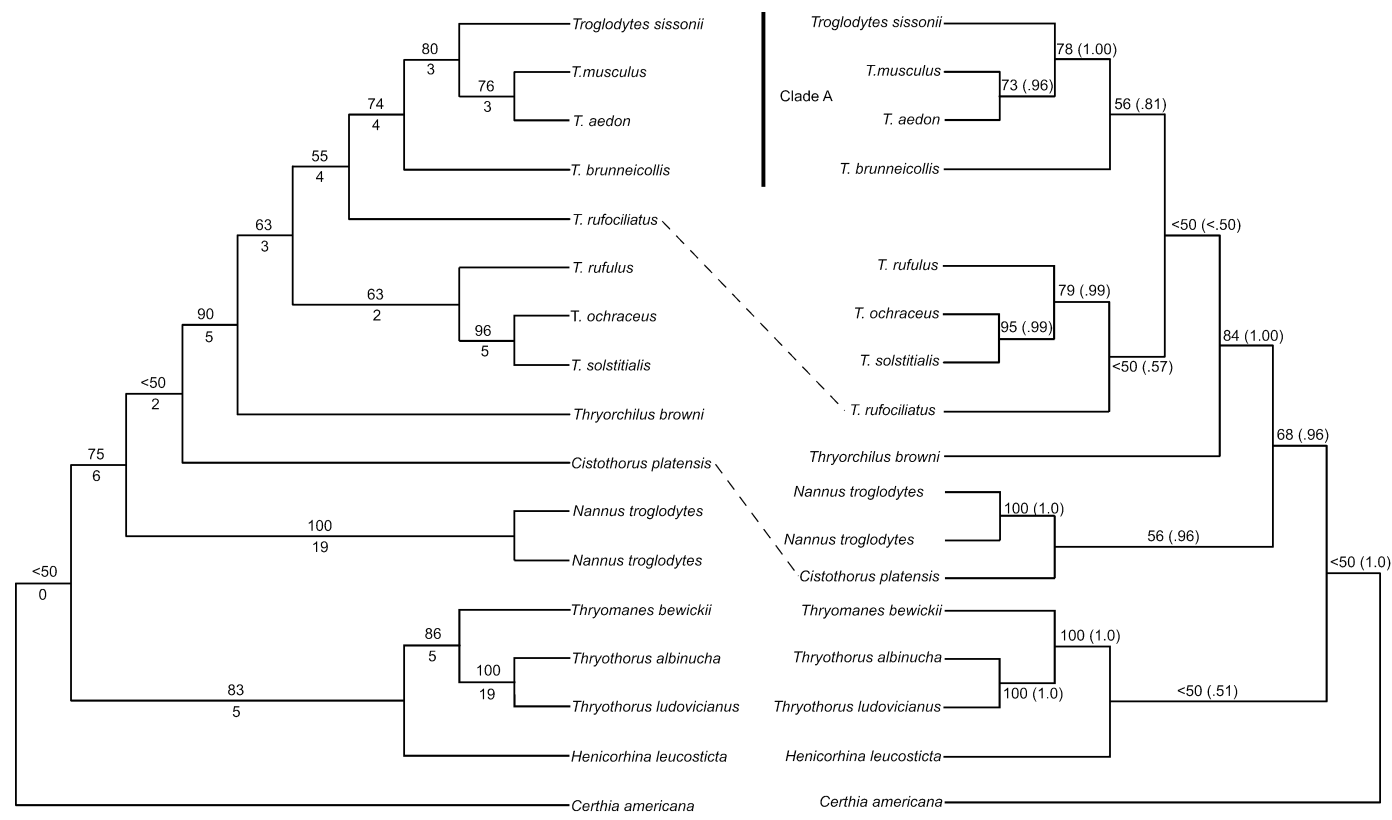

Fig. 1. Phylogenetic hypotheses suggested via maximum parsimony (MP), maximum likelihood (ML), and Bayesian analyses of ND2 mitochondrial DNA sequences. (Left) Topology resulting from equally weighted parsimony analysis. Numbers above lines are bootstrap values; numbers below are Bremer support values. (Right) Topology resulting from ML and Bayesian analyses. Numbers outside of parentheses are bootstrap values for the ML topology, numbers inside are Bayesian posterior probabilities. Bootstrap values for clade A were relatively high in each analysis $(\mathrm{ML}=$ $56, \mathrm{MP}$ equal weights $=74, \mathrm{MP} 2 \times \mathrm{tv} / \mathrm{ts}=72, \mathrm{MP} 4 \times \mathrm{tv} / \mathrm{ts}=71, \mathrm{MP} 8 \times \mathrm{tv} / \mathrm{ts}=67, \mathrm{MP} 10 \times \mathrm{tv} / \mathrm{ts}=65$, Bayesian $=0.81)$. For ML analysis, the following model $(-\ln L=2991.5352$; base frequencies: $\mathrm{A}=$ $0.3076, \mathrm{C}=0.3794, \mathrm{G}=0.0890, \mathrm{~T}=0.2240$; rate matrix: $\mathrm{AC}=1.0, \mathrm{AG}=20.88, \mathrm{AT}=0.8990, \mathrm{CG}=0.8990$, $\mathrm{CT}=6.7244, \mathrm{GT}=1.0$; proportion of invariable sites $=0$; and gamma-shape parameter $=0.3834$ ) was selected by MODELTEST, version 3.06 as the most appropriate model of evolution that explains the data set. The estimated Bayesian parameters were $-\mathrm{ln}=-3015.12 \pm 23.22, \mathrm{~A}=0.312 \pm 0.0003, \mathrm{C}=$ $0.386 \pm 0.0004, G=0.087 \pm 0.00009, T=0.215 \pm 0.003, \propto=0.360 \pm 0.002$ (parameters that were not fixed in the Bayesian analysis and differ from those obtained with MODELTEST). Incongruences between alternative topologies are highlighted with dashed lines. For clarity, branch lengths are not shown.

other members of the genus Troglodytes. Here, using a different outgroup and adding five new taxa to the analysis resulted in the placement of T. troglodytes basal to Thryorchilus browni and the other Troglodytes (and to Cistothorus platensis in one tree). This pattern supports Rice et al.'s (1999) placement of Troglodytes troglodytes as Nannus troglodytes, though its definitive placement will depend on the final position of Cistothorus and Thryorchilus in relation to Troglodytes; the alternative to treatment as Nannus would be a very inclusive Troglodytes.

The phylogenetic hypothesis for Troglodytes in our analysis suggests that the House Wren complex as currently conceived is paraphyletic (clade A, Fig. 1). The House Wren of montane Mexico and the extreme southwestern United States, which has been recognized at the specific level (as T. brunneicollis), is basal to the clade containing the Northern and Southern house wrens (T. aedon and T. musculus; AOU 1998), and the Socorro Wren (Thryomanes sissonii). Hence, to avoid nonmonophyly in a species-level taxonomy, two options are available: (1) lump the entire Thryomanes sissonit + house wren clade into a single inclusive species, Troglodytes aedon, or (2) split the clade provisionally into lowland (T. aedon, T. 
musculus) and highland (T. brunneicollis) species and recognize Troglodytes sissonii.

It has been suggested that the insular forms of house wrens scattered throughout the Caribbean and Pacific islands probably descended from continental lowland forms (Rice et al. 1999), but many aspects of their evolution remain intriguing. The Clarion Wren (T. tanneri) and the Socorro Wren, the only members of the genus in the Revillagigedo Archipelago, may prove to be sister species. However, they differ markedly in size, and their songs have different structures and do not elicit responses in the other species (Howell and Webb 1995, Baptista and MartínezGómez 2002). The Cozumel Wren (T. beani), thought to be a close relative of the Northern House Wren by some authors but considered closely related to the Caribbean house wrens by others (AOU 1998), represents another case that awaits revision. Wrens in the Caribbean are certainly house wrens on the basis of morphology and behavior, but their origins and species limits remain controversial: subspecies of $T$. aedon of recent origin versus distinct species representing much older lineages.

We believe that the most parsimonious course of action at this time is to recognize Troglodytes sissonii, even if disagreement prevails regarding other members of the complex. Several lines of evidence argue for the latter arrangement under both the phylogenetic species concept (PSC) and the biological species concept (BSC). Phenotypic differences between T. aedon, T. musculus, and T. sissonii are marked, making each form a separate entity clearly diagnosable and recognizable under PSC. Moreover, T. brunneicollis and T. aedon exist in broad parapatry across most of Mexico without apparent intergradation (BSC; but see Lanyon 1960).

Moving Thryomanes sissonii to Troglodytes makes interpretation of biogeography much simpler (Rice et al. 1999). If Thryomanes were to include two species (T. bewickii and T. sissonii), the biogeographic interpretation becomes extremely complex; in Mexico, T. bewickii is found primarily in the central highlands; only in Baja California are there lowland populations close to the Pacific coast from which to colonize Socorro Island (Howell and Webb 1995). In Troglodytes, however, the widespread lowland forms (mainly migratory) are well known as excellent colonizers. Hence, the corrected placement of Troglodytes sissonii provides a much more parsimonious biogeographic interpretation of the biogeography of the Islas Revillagigedo (Brattstrom 1990).

\section{Acknowledgments}

We thank J. Dean at the U.S. National Museum of Natural History, and S. Kane at the New York Lyceum, for their assistance in untangling the complex history of publications by Grayson and Lawrence. Permits for collection of tissues were granted by the Instituto Nacional de Ecología-SEMARNAP (permit numbers DOO 700-[2]789, DOO 700-[2]318, DOO 750-2248/97). Lab work was done in the Zink Lab, University of Minnesota. This manuscript benefited from the comments of P. Berendzen, A. W. Jones, J. Pérez Emán, C. D. Cadena, S. J. Hackett, and an anonymous reviewer.

\section{Literature Cited}

American Ornithologists' Union. 1998. Checklist of North American Birds, 7th ed. American Ornithologists' Union, Washington, D.C.

BANKs, R. C., AND M. R. Browning. 1995. Comments on the status of revived old names for some North American birds. Auk 112:633-648.

Baptista, L. F., AND J. E. Martínez-Gómez. 2002. La investigación bioacústica de las Aves del Archipiélago de Revillagigedo: Un reporte de avance. Huitzil 3:33-41.

Brattstrom, B. H. 1990. Biogeography of the Islas Revillagigedo, Mexico. Journal of Biogeography 17:177-183.

Bremer, K. 1988. The limits of amino acid sequence data in angiosperm phylogenetic reconstruction. Evolution 42:795-803.

Bryant, W. E. 1891. Andrew Jackson Grayson. Zoe 2:34-68.

Desjardins, P., and R. Morais. 1990. Sequence and gene organization of the chicken mitochondrial genome. Journal of Molecular Biology 212:599-634.

DrovetsKi, S. V., R. M. ZinK, I. V. FADEev, E. V. Nesterov, E. A. Koblik, Y. A. Red' Kin, AND S. RoHwer. 2004. Mitochondrial phylogeny of Locustella and related genera. Journal of Avian Biology 35:105-110.

Felsenstein, J. 1985. Confidence limits on phylogenies: An approach using the bootstrap. Evolution 79:783-791. 
Grayson, A. J. 1868. Exploring expedition to Socorro Island from Mazatlan, Mexico. California Farmer and Journal of Useful Sciences 29:7.

Grayson, A. J. 1871. On the physical geography and natural history of the islands of the Tres Marias and of Socorro, off the western coast of Mexico. Proceedings of the Boston Society of Natural History 14:261-302.

НАскетт, S. J. 1996. Molecular phylogenetics and biogeography of tanagers in the genus Ramphocelus. Molecular Phylogenetics and Evolution 5:368-382.

Howell, S. N. G., and S. Weвb. 1995. A Guide to the Birds of Mexico and Northern Central America. Oxford University Press, New York.

Huelsenbeck, J. P., and F. Ronquist. 2001. MRBAYES: Bayesian inference of phylogenetic trees. Bioinformatics 17:754-755.

Lanyon, W. E. 1960. Relationship of the House Wren (Troglodytes aedon) of North America and the Brown-throated Wren (Troglodytes brunneicollis) of Mexico. Pages 450-458 in Proceedings XII International Ornithological Congress (G. Bergmann, K. O. Donner, and L. von Haartman, Eds.). Tilgmannin, Kirjapaino, Helsinki.

Lawrence, G. N. 1871. Descriptions of new species of birds from Mexico, Central America and South America, with a note on Rallus longirostris. Annals of the Lyceum of Natural History 10:1-21.

Mayr, E., ANd L. L. Short. 1970. Species taxa of North American birds. Publications of the Nuttall Ornithological Club, no. 9.

McLellan, M. E. 1926. Expedition to the Revillagigedo Islands, Mexico, in 1925, VI.
Proceedings of the California Academy of Sciences 15:279-322.

Oberholser, H. C. 1898. A revision of the wrens of the genus Thryomanes Sclater. Proceedings of the United States National Museum 21: 421-450.

Phillips, A. R. 1986. The Known Birds of North and Middle America: Distribution and Variation, Migrations, Changes, Hybrids, etc. Part I, Hirundinidae to Mimidae, Certhiidae. Published by the author, Denver, Colorado.

Posada, D., and K. A. Crandall. 1998. MODELTEST: Testing the model of DNA substitution. Bioinformatics 14:817-818.

Rice, N. H., A. T. Peterson, and G. EscalonaSegura. 1999. Phylogenetic patterns in montane Troglodytes wrens. Condor 101: 446-451.

Ridgway, R. 1904. The birds of North and Middle America, part 3. Bulletin of the U.S. National Museum, no. 50.

Shimodaira, H., and H. Hasegawa. 1999. Multiple comparisons of log likelihoods with applications to phylogenetic inference. Molecular Biology and Evolution 16: 1114-1116.

SorEnson, M. D. 1999. TREEROT. University of Michigan, Ann Arbor.

Swofford, D. L. 2002. PAUP*. Phylogenetic Analysis Using Parsimony (*And Other Methods), version 4.0b.10. Sinauer Associates, Sunderland, Massachusetts.

TAYlor, L. C. 1951. Prior description of two Mexican birds by Andrew Jackson Grayson. Condor 53:194-197.

Associate Editor: R. M. Zink 